\title{
ESTUDIO COMPARADO SOBRE LOS SUJETOS Y CONTENIDO DE LOS DERECHOS EN LA NORMATIVA CEMENTERIAL MEXICANA, ARGENTINA Y CHILENA. CONTRASTES DESDE SU REGLAMENTACIÓN EN CUBA
}

\author{
COMPARED STUDY ABOUT THE SUBJECTS AND THE CONTENT OF \\ THE RIGHTS IN THE NORMATIVE OF MEXICAN, ARGENTINEAN \\ AND CHILEAN CEMETERIES. CONTRAST FROM THEIR \\ REGULATION IN CUBA
}

\author{
Erick Ortega García* \\ Grethel Arias Gayoso**
}

\begin{abstract}
RESUMEN: El uso privativo de los bienes que integran a los cementerios públicos, entraña una relación jurídica especial entre particular y Administración. Ello implica una bilateralidad entre ambos sujetos, desde el punto de vista sustancial y formal, cuya causalidad resulta un derecho nacido a la vida jurídica bajo las reglas del Derecho Público. En el estudio de los ordenamientos correspondientes a los sistemas mexicano, argentino y chileno, ha sido el último donde se implementa una ordenación coherente para todas sus municipalidades. En contraste, para Cuba, el órgano administrativo no posee una intervención directa sobre las normas que enuncia. Los usos privativos constituidos carecen de una configuración legal que permita determinar los lindes entre sus basamentos público y privado.
\end{abstract}

Palabras claves: sujetos, cementerio, sepultura, relación cementerial, usos privativos.

ABSTRACT: The exclusive use of the goods that they integrate to the public cemeteries, involves a special artificial relationship between matter and Administration. It implies it between both a duality fellow, from the substantial and formal point of view whose causation is a born right to the artificial life under the rules of the Public Right. In the study of the classifications corresponding to the Mexican, Argentinean and Chilean systems, it has been the last one where a coherent ordination is implemented for all its municipalities. In contrast, for Cuba, the administrative organ does not possess a direct intervention on the norms that it enunciates. The constituted exclusive uses lack a legal configuration that allows determining about among their basements public and private.

Keywords: subjects, cemetery, sepulcher, relationship of the cemeteries, private uses.

\footnotetext{
* Máster en Derecho Constitucional y Administrativo por la Universidad de Oriente. Dirección postal: Calle 13 No. 7008 bajos entre 70 y 72, municipio Playa, provincia La Habana, Cuba. Dirección electrónica: erick@ oc.dpvhab.cu.

** Doctora en Ciencias Jurídicas. Profesora Titular de la Universidad de Oriente, Cuba. Dirección postal: Calle San Félix No 313 entre Trinidad y Habana, municipio y provincia de Santiago de Cuba. Dirección electrónica: garias@uo.edu.cu. Número Orcid: 0000-0003-0088-5892
} 


\section{A MODO DE INTRODUCCIÓN: LA RELACIÓN JURÍDICA EN SEDE CEMENTERIAL. EL PROBLEMA ACTUAL DE SUS SUJETOS Y CONTENIDO}

En el desarrollo de su actividad, la Administración Pública cuenta con bienes integrados a su dominio, que conforman el patrimonio administrativo, compuesto tanto por bienes de dominio público ${ }^{1}$, como patrimoniales ${ }^{2}$. En este aspecto, existe consenso en la doctrina internacional ${ }^{3}$ al integrar a la necrópolis dentro del marco jurídico que conforman los bienes del patrimonio público. Sin embargo, el hecho de que los camposantos pertenezcan al dominio público municipal enfrenta a las relaciones que tienen lugar en los diferentes ámbitos del Derecho. Así, se evidencian dos grupos fundamentales, las que se propician entre el municipio y el particular (derecho público) y entre el particular y la sepultura (relación de derecho administrativo $)^{4}$.

Sobre todo cementerio, tanto los públicos como los privados, concurren potestades públicas, potestades de las confesiones religiosas y potestades o derechos de los sujetos particulares que son usuarios del servicio de cementerio. Todo ello, con independencia de las potestades que correspondan a las entidades privadas que tengan la condición de gestoras del servicio público de cementerio, cuyos límites y contenido dependerá en cada caso concreto de los pliegos de concesión y permiso, de los estatutos de las sociedades encargadas de la prestación del servicio público y, en general, de los acuerdos municipales en los que se opte por uno o por otro sistema de gestión 5 .

El uso privativo de los bienes que integran a los cementerios públicos, entraña una relación jurídica especial entre el particular y la Administración, que conlleva una serie de garantías fundadas en la preeminencia del interés general sobre el particular. Bien sea constituida mediante el permiso o la concesión de uso, esta relación implica una bilateralidad entre ambos sujetos, desde el punto de vista sustancial y formal. Ello se debe a que en su contenido deben concurrir las voluntades de las partes intervinientes en la relación. Aunque, evidentemente por el ámbito objetivo y las consecuencias de la relación, se trata

\footnotetext{
1 El criterio determinante de los bienes demaniales es su afectación a un uso general o servicio público. Debe existir una relación de inmediatividad entre el bien afectado y el uso o servicio público, y encontrarse protegidos por un régimen regulatorio exorbitante. HAURIOU (1929) pp. 162-188; MAYER (1950) p. 121; Ballesteros (1990) pp. 23-26.

2 La definición de los bienes patrimoniales es negativa y residual, al incluir a todos los que, siendo de titularidad de la Administración Pública, no tienen el carácter de demaniales. Susceptibles de resultar fuente de recursos, también son objeto de una afectación indirecta o mediata, al cumplimiento de fines de interés general. Por ello se rigen por las normas de Derecho privado, en defecto de legislación específica. GarCÍA DE EnTERRÍA y Fernández (1997) pp. 93-112; Parada (1988) p. 164; Ballesteros (1990) pp. 28-29.

3 SÁNChez (1997) p. 37; HeRnández (2008).

4 Desde una perspectiva jurídica en los cementerios concurre una doble condición: tienen una significación religiosa consustancial y, al propio tiempo, poseen una relevancia jurídica-pública, atribuida a partir de finales del siglo XVIII y consolidada a lo largo del siglo XIX. Ambos aspectos producen consecuencias en la esfera del Derecho y son determinantes en la configuración de su régimen jurídico. Rodríguez (2015) p. 49. Al efecto Fernández de Velasco aduce que las cosas espirituales, como lo son las cosas destinadas al culto y los cementerios, no obstante a la profanación de la que hayan podido ser objeto, no pueden ser apropiables, por no estar en el comercio de los hombres. Fernández de Velasco (1935) p. 178.
}

5 Rodríguez (2015) p. 72. 
de una participación desigual. A la Administración Pública le corresponderá entonces un mayor poder de decisión. Sus consecuencias trascienden a las partes, al afectar el uso y trasmisión de estos bienes a terceros ${ }^{6}$.

De esta forma, puede identificarse como sujeto activo de la relación al Estado ${ }^{7}$, quien ejerce su función directa a través de las empresas y entidades que a tales efectos crea, resultando así un sujeto determinado. Precisamente, al no existir la res nullius, se impide que cualquier persona pueda apropiarse de ellos al permanecer integrados al dominio público, en cuyo caso no habría razón alguna para su existencia ${ }^{8}$. El sujeto pasivo o usuario en esta relación, a diferencia de los usos comunes, no será indeterminado o genérico, constituido por la colectividad. En todo caso es específico, representado y compuesto exclusivamente por los titulares de los correspondientes derechos otorgados por el Estado sobre las unidades físicas que componen el cementerio. Cuestión esta que permite individualizar al usuario?. En este desigual ámbito, y en virtud de su titularidad originaria, la Administración Pública mantiene las facultades precisas para asegurar el cumplimiento del fin contemplado por el ordenamiento. Así, ejerce la función administrativa, a partir del conjunto de potestades que, inherentes a su actuar, coadyuvan a la defensa del patrimonio demanial. Estas devienen en mecanismos de autotutela, ante violaciones en el uso de los derechos subjetivos otorgados; dentro de las que figura la potestad de investigación, de deslinde, de recuperación de oficio, de desahucio, sancionadora y la publicidad posesoria del demanio que dispensa el Registro de la Propiedad. Las limitaciones administrativas impuestas sobre los derechos privados reconocidos en cementerios públicos, llegan a ser de diversos tipos: las denominadas meras restricciones, ocupación temporánea, requisiciones, expropiación y servidumbres. Su postulación generalizada y expresa en el ordenamiento jurídico, permiten su existencia independiente a la voluntad de las partes. De esta forma, el acto mediante el cual se reconoce derechos sobre sepulturas y panteones, solo vendría a concretar, sobre un supuesto determinado, el contenido y ejercicio de la potestad involucrada por medio de la cual la Administración garantiza el cumplimiento del fin por el cual fue reconocido ese derecho ${ }^{10}$.

\footnotetext{
${ }^{6}$ Es criterio de esta investigación, la coincidencia en el régimen jurídico de los cementerios públicos, del tratamiento de concesiones y permisos de uso de sepulturas. Aunque resultan medios independientes en su contenido y alcance, encuentran en este régimen un similar tratamiento constitutivo. Es por ello que resulta apropiable el diseño de la naturaleza jurídica de las concesiones administrativas observado por el profesor Andry Matilla Correa. Matilla (2005) p. 52.

7 Existen dos corrientes doctrinales en cuanto a la titularidad del dominio público, que se atribuye por un sector al pueblo, y por otro al Estado. Coincide esta investigación con el profesor Villegas Basavilbaso al exponer que los autores que tienen al pueblo como sujeto del dominio público, consideran bienes públicos únicamente los afectados al uso directo de la colectividad, no a los bienes patrimoniales del Estado afectados al uso indirecto (al servicio público), sobre los cuales el Estado tiene un verdadero derecho subjetivo. ViLlegas (1952) p. 170.

8 Ranelletti (1897) p. 374; Guicciardi (1934) p. 28; Ballbé (1948) p. 9; Laubadère (1958) p. 738; García de Enterría y Fernández (1997) p. 48; Garrido (1986) p. 478.

9 Marienhoff (1960) p. 153

${ }^{10}$ Matilla (2005) pp. 62-63.
} 
Por su parte, el usuario, tiene un carácter intuitu personae ${ }^{11}$. A pesar de la poca trascendencia que para esta relación jurídica posee, esta condición origina derechos para el concesionario. Estos derechos permiten un uso directo y efectivo sobre la parte de la cosa pública (sepultura) que le ha sido entregada ${ }^{12}$. Como especificidad en esta relación destaca la necesaria existencia del interés directo e inmediato del usuario para que pueda tener lugar, por lo que predomina su interés privado sobre el público ${ }^{13}$. Entonces, la contraprestación a cargo del usuario, consiste en aumentar el bienestar público, mediante el buen uso del bien demanial. Este bienestar social se logra como consecuencia del beneficio particular que recibe la Administración a partir del uso del bien (sepultura) acorde al destino de la cosa demanial ${ }^{14}$.

En este contexto se inserta como elemento causal de la relación jurídica en sede cementerial, un derecho nacido a la vida jurídica, bajo los principios y reglas del Derecho Público. Así, se trata de un acto plenamente administrativo que aprueba un uso privativo estatal. Esto conlleva a que las relaciones del usuario con otros particulares se rigen por el derecho privado, siempre que no exceda los límites trazados por el Derecho Administrativo. De esta forma, es la Administración, quien, a partir de su reglamentación general, y específica para cada recinto cementerial ${ }^{15}$, establece el cuidado y acondicionamiento del cementerio. Los reglamentos de régimen interior de los cementerios son aprobados por la corporación municipal de la que depende la necrópolis y su contenido versa sobre la identificación de los servicios del cementerio; las condiciones para el otorgamiento de concesiones y permisos de sepulturas; las tasas por la ocupación de terrenos y licencias de obras; el nombramiento y remoción de empleados; y el Registro de sepulturas, entre otras.

El derecho privado en el uso del bien cementerial, queda limitado a la conservación de cadáveres y restos humanos, de acuerdo con las condiciones y duración de su otorgamiento. También y tratándose de concesiones, dispone la ordenación de inhumaciones, exhumaciones, reducción de restos y otras prestaciones reconocidas. Determina a su vez los epitafios, recordatorios, emblemas y símbolos de la unidad de enterramiento, previa autorización de la Administración, y de acuerdo con las normas que rijan la materia. Alcanza a la realización de obras y construcciones particulares, siempre que el derecho funerario adquirido faculte para ello, y de acuerdo con las exigencias prescritas por la normativa cementerial. El usuario tiene la obligación de solicitar licencia para la realización de obras sobre una sepultura que incluye la colocación de estatuas, floreros y jardineras que sobresalgan de la edificación, y de legalizar las actuaciones realizadas por vía de hecho. Sobre estas obras y construcciones el usuario posee un derecho real con las atribuciones propias del propietario, sin perjuicio de que tengan que ser demolidas a cargo del usuario o reviertan

\footnotetext{
11 El carácter personal intuitu personae no significa que los derechos derivados de la relación jurídica no sean transmisibles, sino que su cesión no puede hacerse libremente, sino con autorización administrativa. LópEZ Pellicer y Sánchez (1976) p. 147.

12 Mayer (1950) p. 248.

13 Cammeo (1926) p. 905.

14 Marienhoff (1960) p. 180

15 Rodríguez (2015) pp. 99-101.
} 
a la Administración una vez extinguidos a la concesión. También puede exigir la adecuada conservación, limpieza general del recinto y cuidado de las zonas comunes.

Así mismo, inscribe el derecho cementerial en el Registro de la Propiedad ${ }^{16}$, y lo transmite, tanto inter vivos como mortis causa, de acuerdo con los requisitos establecidos en las normas administrativas específicas. Para ello, la designación de beneficiario de la transmisión, corresponde al titular del derecho cementerial. En atención a la concurrencia de derechos privados y de disposiciones de Derecho Público, deben respetarse las normas civiles sobre transmisión de bienes inmuebles. En las transmisiones mortis causa, en ausencia de designación expresa de un beneficiario, habrá que regirse por lo que establezcan las normas civiles respecto a la sucesión, que operan como dato previo que ha de tener en cuenta la Administración en el ejercicio de sus potestades, aunque la ausencia de concreción del heredero de la concesión demanial concernida, no obliga a la jurisdicción contencioso-administrativa a suspender el proceso, o a remitir a las partes a la autoridad civil. Por último, la Administración no puede interpretar disposiciones testamentarias en términos que restrinjan los derechos de los herederos a la titularidad de la concesión demanial. En general, el usuario posee el derecho a exigir la prestación de todos los servicios que incluye la actividad de cementerio, de acuerdo con la reglamentación del servicio.

En correlación, el usuario posee medidas de obligado cumplimiento por el uso privativo de la porción de dominio público sobre la que se extiende la autorización. Ello implica, la conservación del título de derecho cementerial expedido, cuya acreditación será preceptiva para atender la solicitud de demanda de prestación de servicios o autorización de obras. En caso de extravío, deberá notificarse a la Administración para la expedición de un nuevo título acreditativo. Para la realización de obras, abonará las cantidades que correspondan por tal concepto, y dispondrá de las medias necesarias para asegurar el cuidado, conservación y limpieza de las obras de construcción particular realizadas.

De igual forma, en el aspecto exterior de la unidad de enterramiento, se limita al usuario en la colocación de elementos ornamentales al espacio físico asignado. Debe abonar las tasas correspondientes a las prestaciones o licencias solicitadas, de acuerdo con la norma fiscal vigente. La falta de abono de las tasas, dará lugar a la extinción del derecho cementerial. En todo momento, se le exige un comportamiento adecuado en el recinto del cementerio, en consonancia con la finalidad del lugar. Las obras e inscripciones deberán respetar la función del recinto, concediéndose las autorizaciones y licencias de obras, sin perjuicio de terceros.

La falta de diligencia de la Administración, en su obligación de garantizar los derechos del usuario o su incumplimiento, lo faculta para exigir responsabilidad patrimonial, y

16 La doctrina argentina, siguiendo las ideas de autores franceses, sostiene que no son inscribibles los documentos en los que conste la trasmisión de derechos sobre sepulcros, en cualquiera de sus variantes o características. CoRnejo (1994) p. 73; Ducroce (1900) pp. 316, 356. Sin embargo, la doctrina española, a la que se afilia esta investigación, se apoya en otros autores, para dar por sentado que los derechos funerarios que adquiere un particular sobre las sepulturas de un cementerio público, son concesiones demaniales de uso privativo de un bien de dominio público, las que se deben formalizar en documento administrativo, que será título suficiente para su inscripción en el Registro de la Propiedad. RodríGuez (2015) p. 104. En este sentido, HAURiou (1929) p. 271, además de la mayoría de la doctrina posterior que defiende la figura, así como aquellos que no se plantean el problema del derecho real administrativo, como BiELSA (1956) pp. 403-407. 
obtener la consiguiente indemnización ${ }^{17}$. De igual manera, la inobservancia de las normas cementeriales y la infracción de las obligaciones del usuario, legitima a la Administración para imponer sanciones, e incluso, cesar el derecho concedido. Para estas y otras cuestiones que involucra la solución de conflictos originados en torno a los bienes cementeriales, ha sido la Administración Pública, en su función de sujeto activo representante del poder estatal, quien ha desempeñado una encomiable labor, como máxima juzgadora en observancia de las disposiciones vigentes al respecto.

El régimen expuesto, en cuanto a los sujetos y contenido del tratamiento jurídico de los cementerios públicos, si bien se encuentra muy desarrollado en la doctrina, la práctica latinoamericana dista mucho de su aplicación y coherencia. En ello influye, además del sustrato normativo heredado desde la colonización, los arraigos autóctonos en cuanto a la concepción de la muerte y su trascendencia social y jurídica. De esta forma, muchas son las características y distinciones que pueden encontrarse en esta área geográfica, que van desde un abierto y discordante sistema regulatorio que incluyen tanto el reconocimiento de propiedades civiles como el arrendamiento, hasta un cerrado régimen concesional que impide la trasmisión mediante actos inter vivos.

Desde estas premisas doctrinales, en el presente artículo se ofrece un estudio comparado del tratamiento de los sujetos y contenido de la relación jurídica cementerial, que posibilitará contrastar y determinar las principales tendencias seguidas por ordenamientos pertenecientes al sistema de derecho latino o romano francés, dentro de ellos, México y Argentina, a partir de sus arraigadas concepciones en la regulación de los cementerios públicos, que ilustran las perspectivas normativas asentadas en América Latina; y Chile, cuyas regulaciones de última generación en torno a la conformación jurídica del régimen aplicable a los cementerios públicos, marcan pautas en el ámbito latinoamericano. En contraposición, se analizan las incidencias cubanas en el tema, con el fin de lograr una caracterización de la regulación cementerial desde el entorno patrio, que delimite los aspectos que trascienden a este derecho.

La metodología de la investigación se enfoca en cuanto a los sujetos que intervienen en la relación jurídica cementerial y derechos reconocidos sobre bienes cementeriales. En correspondencia, se utilizaron los métodos: histórico-lógico que posibilitó enfocar el objeto de estudio, la relación jurídica cementerial, destacando los contextos históricos y las etapas de su desenvolvimiento en cada ordenamiento estudiado; el inductivo-deductivo, que propició su sistematización como institución jurídica y el diagnóstico de las principales insuficiencias que existen en Cuba, a partir de las posturas seguidas por los sistemas normativos en análisis; y el análisis-síntesis, permitió distinguir las particularidades del régimen jurídico de los cementerios públicos y su regulación en las regulaciones investigadas.

En correspondencia a los métodos descritos, se utilizaron las técnicas de análisis documental, que posibilitó acopiar la información necesaria sobre el tema, de análisis de reglamentos, ordenanzas y otras normas relacionadas con la regulación de los cementerios públicos en diferentes contextos geográficos y socioculturales, con el fin de desarrollar los

\footnotetext{
17 Al respecto, Martín-Retortillo (1963) pp. 453-489; Navarro (1988) pp. 603-678; Beladiez (1997) p. 132.
} 
objetivos propuestos, así como el procesamiento de información. Todo ello permitió identificar sus correspondencias y diferencias, para brindar veracidad a los resultados obtenidos.

\section{LA REGULACIÓN ADMINISTRATIVA DE LOS CEMENTERIOS PÚBLICOS DESDE UNA PERSPECTIVA COMPARADA.}

En el ámbito internacional, la protección más significativa de cementerios y sepulturas es la que se ofrece en el marco de los cuatro Convenios de Ginebra, de 12 de agosto de $1949^{18}$. Su contenido versa sobre la protección internacional del derecho de la persona a recibir sepultura digna. Tutela que exige la protección de los lugares de enterramiento ${ }^{19}$. Desde este paradigma, se instrumentan regulaciones nacionales, con el fin de brindar respaldo legal a su constitución y funcionamiento. En este sentido, debe señalarse el entramado penal, civil y administrativo que debe contener las disposiciones en torno a la regulación del uso de los bienes cementeriales. Los cementerios, en todas las épocas han estado urgidos de una protección integral, como parte de una acción integradora de todo el ordenamiento jurídico. Tanto las normas constitucionales, como penales, civiles y administrativas, juegan un papel preponderante en su régimen regulatorio ${ }^{20}$

Requiere entonces, de un precepto constitucional que, a partir de la consagración de derecho a recibir sepultura digna, responsabilice a la Administración Pública y sus entes, con la protección de cementerios cementeriales públicos. La norma penal complementa las sanciones contra hechos constitutivos de delitos, que atente contra la seguridad, integridad y decoro en el tratamiento de cadáveres, cementerios y sus bienes ${ }^{21}$. Se conjuga la regulación civil en el ámbito de reconocimiento de derechos entre usuarios del servicio del cementerio $^{22}$, y finalmente, será la regulación administrativa, quien organice su funcionamiento, otorgue permisos y concesiones, y vele por el cumplimiento de los requerimientos administrativos en el uso de los bienes cementeriales.

En el contexto latinoamericano, México define a los panteones y cementerios como parte del servicio público a cargo de los municipios. Así lo refiere en el inciso e) fracción III del artículo 115 de la Constitución Política de los Estados Unidos Mexicanos ${ }^{23}$. La actividad administrativa del municipio en México se encuentra enmarcada en la Constitución fe-

\footnotetext{
18 Los Convenios de Ginebra los integran: I. Convenio para aliviar la suerte que corren los heridos y los enfermos de las fuerzas armadas en campaña. II Convenio para aliviar la suerte que corren los heridos, los enfermos y los náufragos de las fuerzas armadas en el mar. III Convenio relativo al trato debido a los prisioneros de guerra. IV Convenio relativo a la protección debida a las personas civiles en tiempo de guerra y Protocolos adicionales. Convenios de Ginebra y sus Protocolos Adicionales de 1949.

19 El artículo 130 del IV Convenio establece que las autoridades en cuyo poder estuvieron los internados se ocuparán de que los fallecidos en cautiverio sean enterrados dignamente, si es posible con arreglo a los ritos de la religión a que pertenezcan, y de que sus sepulturas sean respetadas, convenientemente conservadas y marcadas de modo que se las pueda localizar en cualquier momento. RodríGUEz (2015) pp. 195-197.

20 García (2006) p. 6.

21 Terradillos (2010) pp. 424-461; García (2006) p. 62.

22 Parejo (2009) pp. 228-229.

23 Constitución Política de los Estados Unidos Mexicanos (26/2/2013).
} 
deral, la Constitución de los Estados y leyes estaduales expresas, que regulan la estructura y funcionamiento de la Administración municipal. Por lo que, a partir de estas disposiciones, se instrumenta la gestión del servicio de cementerios, de forma prioritaria e ineludible por los Gobiernos Municipales. En tal sentido, cada municipalidad orienta su propio Reglamento de Cementerios para la organización, administración y conservación de los cementerios ubicados en su localidad ${ }^{24}$.

Sin embargo, si bien el servicio de cementerio posee una esencia pública, este ordenamiento se restringe a la tendencia española ${ }^{25}$, liberalizando la gestión privada de cementerios. De esta forma, concesiona los servicios funerarios que comprenden desde el fallecimiento, hasta el acto del sepelio, incluyendo los rituales funerarios y velatorios. Para ello, estas empresas privadas cuentan con locales habilitados al efecto. Sus reglamentos municipales instrumentan la naturaleza y extensión del derecho funerario de estos entes privados $^{26}$. Se aprecia como la Administración pública mexicana va desentendiéndose de un servicio que, por sus implicaciones sociales requiere desempeñar un continuo trabajo de supervisión y control. En materia de cementerios, serán aplicables la Ley Orgánica Municipal, la Ley de Hacienda Municipal, las Leyes de Salud tanto Federal como Estatal, el Reglamento Interior del Ayuntamiento, el Reglamento municipal de cementerios y las demás que puedan ser aplicables al caso concreto. A ello se suma que la legislación municipal es casi desconocida por los que habitan el municipio, adquiriendo mayor interés y demanda las que emanan del poder federal.

En otro contexto, la realidad argentina, con mayor incidencia que en la administración mexicana, muestra la privatización de casi la totalidad de los servicios públicos. Esta operación privatizadora comprende todas aquellas empresas que no cumplían funciones esenciales o indelegables del Estado. Desde empresas que tenían por objeto meras actividades comerciales o industriales, las reguladas por el Derecho administrativo en virtud del interés público, hasta los servicios públicos tradicionales. Así, todo un variado universo de empresas fue declarado por ley, sujeto a privatización ${ }^{27}$. En tal situación también fueron incluidos los servicios del cementerio ${ }^{28}$.

En materia de regulación de cementerios, el territorio argentino al igual que el mexicano, carece de una norma nacional. Son los municipios quienes por mandato constitucional ${ }^{29}$, y a través de sus disposiciones (Ordenanzas), establecen el marco regulador para cada

\footnotetext{
24 Así se expresa en la Exposición de los Motivos del Reglamento de El Oro de 2014.

25 En España, país con un complicado sistema jurídico de normas nacionales, provinciales y municipales engarzadas sobre una misma materia, el cementerio es un servicio municipal de obligación mínima, que las entidades locales tienen la responsabilidad de prestar por sí o asociadas con otras. Se exceptúan las que sean expresamente dispensadas por la autoridad autonómica por resultar imposible o muy difícil su cumplimiento. De este modo, los cementerios municipales pueden ser gestionados directamente por corporaciones locales o sociedades que adopten el sistema de empresa mixta o de capital privado.

26 Así lo reconoce el artículo 84 de la Ley No 7 de 1985, en relación al artículo 22 del ReAl Decreto Ley No 7 de 1996. Tal como referencia los artículos 1 y 2 inciso de la Ordenanza de Guadalajara de 1998.

27 Cassagne (2001) pp. 441-461.

28 Fernández, et al. (2016) pp. 273-282.

29 Conforme al artículo 5 en relación con el 123 de la Carta Magna argentina, cada provincia dicta su propia constitución, asegurando la autonomía municipal y reglando su alcance y contenido en el orden institucional,
} 
localidad en específico. En efecto, las provincias, a través de sus constituciones y leyes orgánicas municipales, delegan parte de sus atribuciones en los municipios que las conforman. En las ordenanzas estudiadas, las municipalidades imponen su jurisdicción en la instalación y administración de cementerios, fundadas en razones higiénicas y de orden público ${ }^{30}$.

Por su parte, la ordenación de cementerios chilenos, con mayor acierto que los regímenes anteriormente referidos, reconoce la autoridad gubernamental para regular los públicos; en tanto consiente la creación de $\operatorname{privados}^{31}$. De este modo, las normas vigentes en materia de cementerios e inhumaciones, se enmarcan en el Código Sanitario ${ }^{32}$, el Código Civil ${ }^{33}$ y el Reglamento General de Cementerios ${ }^{34}$. Estas disposiciones generales permiten homogeneizar las regulaciones municipales en torno a los cementerios públicos. Además, el Estado garantiza y mantiene el exclusivo control sobre aquellos cementerios que garantizan este servicio público, sin impedir que pueda generarse otras prestaciones de este propio servicio a través de entes privados. No obstante, a pesar del claro destino de servicio público que desarrollan tanto los cementerios sujetos a instituciones del Estado, como los de propiedad del Servicio Nacional de Salud y de las municipalidades, no existe un reconocimiento normativo expreso de esta condición. Solo algunos Reglamentos de cementerios municipales poseen referencias al respecto ${ }^{35}$. Los textos locales consultados en la regulación mexicana ${ }^{36}$ reconocen a los cementerios como bienes de servicio público pertenecientes al Ayuntamiento, sometidos a su administración, cuidado y dirección. Sin embargo, se aprecia una indefinición de regímenes público y privado de cementerios. Esta situación se suscita ante la posibilidad de concesionar la operación del servicio público de cementerios, tanto en establecimientos públicos ${ }^{37}$, como privados $^{38}$, implementando los requisitos de los

político, administrativo, económico y financiero. Constitución Nacional de la República Argentina (22/8/1994).

30 Artículo 1 de la Ordenanza No 838 de Santiago del Estero de 1983; Artículo 1 de la Ordenanza No 3306 de San Miguel de Tucumán de 2003; Artículo 1 de la Ordenanza No 545 de Lomas de Zamora de 1915.

31 Serrano (2009) p. 222; Irarrázaval (2018) pp. 33-56.

${ }^{32}$ Libro VIII "De las inhumaciones, exhumaciones y traslado de cadáveres", artículos del 135 al 144 del DeCRETO con Fuerza de Ley No 725 de 1967.

33 El Código Civil chileno, en su artículo 587 dispone que el uso y goce de las capillas y cementerios, situados en posesiones de particulares y accesorios a ellas, pasarán a las personas que sucesivamente adquieran las posesiones en que están situados, a menos de disponerse otra cosa por testamento o por acto entre vivos. Código Civil de Chile de 2000.

34 Decreto No 357 de 1970.

35 Resolución No 6l-G. G de Valparaíso de 2017 en su artículo 2 dispone que por la característica de servicio de utilidad pública que el Cementerio presta a la comunidad, este reglamento contiene las normas a las cuales deben ceñirse los Titulares de sepulturas, sus herederos y cesionarios, o propietarios a cualquier título y en general todas las personas que ingresen al recinto.

36 Reglamento de Bolaños; Reglamento de El Oro de 2014; Reglamento de Fresnillo; Reglamento de Güeñes; Reglamento del Distrito Federal de 1984.

37 Primer párrafo de la Exposición de los Motivos del Reglamento de Bolaños; artículo 3 del Reglamento de El Oro de 2014; artículo 1 del Reglamento de Fresnillo; artículo 1 del Reglamento de Güeñes; artículo1 de Reglamento de Distrito Federal de 1984.

${ }_{38}$ Para los municipios, tal como refieren sus respectivos Reglamentos, los cementerios particulares o privados son considerados concesiones municipales otorgadas mediante acuerdo de Cabildo. Gestionados por personas naturales o jurídicas (morales), se les autoriza la venta de lotes y el mantenimiento de sus instalaciones. 
sujetos del derecho funerario. El uso de estas dependencias cementeriales se revierte a la municipalidad una vez vencido el plazo de la concesión otorgada (15-30 años).

Destaca la regulación del Reglamento Municipal de Cementerios de la localidad de Güeñes. A contracorriente, su normativa reconoce el estricto y exclusivo sometimiento de todos sus cementerios a la administración, cuidado y dirección de la Corporación municipal, sin perjuicio de las facultades que correspondan a la Autoridad Judicial y Sanitaria ${ }^{39}$. Así se reserva, entre otras funciones, el acondicionamiento de los cementerios, las construcciones funerarias, los servicios e instalaciones. El otorgamiento de las concesiones sepulcrales y reconocimiento de los derechos funerarios de cualquier clase. La percepción de los derechos y tasas que se establezcan legalmente por la ocupación de terrenos, licencias de obras y concesiones de derechos funerarios ${ }^{40}$.

Las ordenanzas cementeriales argentinas reconocen a su vez, los deberes y atribuciones de las direcciones de cementerios municipales. Así, se responsabilizan con el cumplimiento de sus obligaciones administrativas, limpieza, control de trabajos, inspección de obras ${ }^{41}$. Además, inspeccionan los monumentos, a efectos de verificar el cumplimiento de las normas vigentes o cuando las necesidades del servicio así lo requieran ${ }^{42}$. Asimismo, poseen a su cargo el Registro de Concesiones y Transferencias de la Administración, conformado por el Registro Gráfico, con la planimetría de las manzanas y lotes; y el Registro Escrito sobre concesiones y/o transferencias de terrenos ${ }^{43}$.

Tal como sucede en el régimen mexicano, la regulación propia de cada municipalidad, hace que varíe entre una y otra la amplitud de los derechos concedidos sobre sepulturas. De este modo, para la municipalidad de Santiago del Estero, la concesión de terrenos se efectúa por el término de 40 años, contados a partir de la fecha del decreto de adjudicación ${ }^{44}$. Además, los derechos sobre las concesiones son intransferibles, ya sea a título oneroso o gratuito. Se exceptúan las transferencias por fallecimiento del titular, o las que de sus partes indivisas hagan los coadjudicatarios entre $s^{4}{ }^{45}$. Subsiste así, un régimen concesional a

Aún así son incompetentes para efectuar actos que atañen exclusivamente a las autoridades municipales, tales como las inscripciones en Registros Públicos. Por lo tanto, devienen en simples fraccionamientos del cementerio municipal, aptos para efectuar actos de inhumación y exhumación de cadáveres. Artículos 20 y 21 del Reglamento de Bolaños. Artículos 7.II y 9 del Reglamento de El Oro de 2014. Artículos 16 y 17 del Reglamento de Fresnillo. Artículos 7.II y 16 del Reglamento del Distrito Federal de 1984.

39 Artículo 1 del Reglamento de Güeñes.

40 Artículo 2, del Reglamento de Güieñes.

41 Artículo 56 inciso c) de la Ordenanza No 838 de Santiago del Estero de 1983; Artículos 56 y 85 de la Ordenanza No 3306 de San Miguel de Tucumán de 2003; Artículos 3; 23 y 55 de la Ordenanza No 545 de Lomas de Zamora de 1915.

42 Artículo 56 inciso g) de la Ordenanza No 838 de Santiago del Estero de 1983; Artículo 36 de la Ordenanza No 3306 de San Miguel de Tucumán de 2003; Artículos 3 y 4 de la Ordenanza No 4200 de Lomas de Zamora de 1984.

43 Artículos 13; 50-54 de la Ordenanza No 838 de Santiago del Estero de 1983; Artículo 34 inciso b) de la Ordenanza No 3306 de San Miguel de Tucumán de 2003; Artículo 59 de la Ordenanza No 545 de Lomas de Zamora de 1915.

44 Artículo 9 de la Ordenanza No 838 de Santiago del Estero de 1983.

45 Artículo 15 de la Ordenanza No 838 de Santiago del Estero de 1983. 
perpetuidad no declarado, pues otorga una nueva concesión, dentro del transcurso del año de su vencimiento, por otros 40 años, sucesivamente ${ }^{46}$.

De este modo, el enramado cementerial chileno supera a las regulaciones mexicana y argentina, al configurar un sistema uniforme con alcance nacional. En este sentido, el Código Sanitario reconoce al Servicio Nacional de Salud, como el único ente estatal que autoriza la instalación y funcionamiento de cementerios ${ }^{47}$. Estipula la obligación de las municipalidades de establecer cementerios en los lugares en que no los hubiere o fueren insuficientes ${ }^{48}$. Además, dispone la implementación de un Reglamento que regirá para la instalación y funcionamiento de todos los cementerios ${ }^{49}$. En consecuencia, se promulga el Reglamento General de Cementerios.

En este sentido, el Reglamento General de Cementerios regula dos clases de cementerios. De un lado, los generales o públicos, que pertenecen a alguna institución del Estado, ya sean propiedad del Servicio Nacional de Salud o de las municipalidades. Del otro, los particulares de determinados cultos religiosos; los de colonias extranjeras; los de indígenas, entre otros ${ }^{50}$. Con independencia a su clase todo cementerio estará a cargo de un Director o Administrador, que responderá ante la autoridad sanitaria. Sus obligaciones se establecen en los Reglamentos internos de los cementerios ${ }^{51}$. Este Reglamento ordena, además, de modo general, las clases de sepulturas constituidas en todo cementerio. De acuerdo con su extensión en el tiempo, estas pueden ser perpetuas, o temporales a largo o corto plazo $^{52}$. No obstante, cobija derechos civiles y administrativos bajo una misma sombra legislativa. Así, como perpetuos nacen los derechos de los propietarios fundadores de una sepultura de familia y de sus parientes, a ser sepultados en ella ${ }^{53}$. Las sepulturas temporales a largo plazo se otorgan por $20 \mathrm{años}^{54}$, pudiendo renovarse por una sola vez por igual período. Por su parte, las temporales a corto plazo se otorgan por 5 años, renovables por períodos iguales y sucesivos hasta 20 años ${ }^{55}$.

La confusión existente en el régimen mexicano de los cementerios públicos y privados, conlleva a un amplio marco regulatorio de las sepulturas. Se aprecia así, dentro del propio contexto nacional, una distancia entre aquellos sistemas normativos que reconocen un derecho exclusivamente concesional, de otras que instrumentan un derecho de propiedad sobre las concesiones a perpetuidad. En ningún caso se reconoce la posibilidad de inscripción registral de los derechos otorgados, cuya ausencia sugiere su nulo tratamiento en este sistema jurídico. Tal es así, que, por un lado, el Reglamento de Cementerios de Bolaños, reconoce el derecho de toda familia a adquirir a perpetuidad, un terreno o cripta de los panteones

\footnotetext{
46 Artículo 17 de La Ordenanza No 838 de Santiago del Estero de 1983.

47 Artículo 136 del Decreto con Fuerza de Ley No 725 de 1967.

48 Artículo 138 del Decreto con Fuerza de Ley No 725 de 1967.

49 Artículo 136 del Decreto con Fuerza de Ley No 725 de 1967.

50 Artículo 15 del Decreto No 357 de 1970.

51 Artículo 14 del Decreto No 357 de 1970.

52 Artículo 29 del Decreto No 357 de 1970.

53 Artículo 41 del Decreto No 357 de 1970.

54 Artículo 32 del Decreto No 357 de 1970.

55 Artículo 33 del Decreto No 357 de 1970.
} 
municipales en servicio. Reconocido a través de un título de propiedad, otorga un derecho intransferible, inembargable, e imprescriptible. Solo podrá ser trasmitido al fallecimiento del titular, a favor de familiares dentro del cuarto grado de consanguinidad ${ }^{56}$. Por otro, el Reglamento de Cementerios de El Oro, si bien considera al derecho sobre sepulturas como intransferible, inembargable e imprescriptible, no acepta la perpetuidad en las concesiones, concediéndola por 7 años prorrogables por única vez por término idéntico ${ }^{57}$.

Desde otra práctica, la municipalidad argentina de San Miguel de Tucumán instrumenta concesiones de terrenos por el término de 5 años. Además, pueden renovarse y transferirse, autorizando las cesiones gratuitas y onerosas, ya sean inter-visos o mortis causa, de la totalidad o parte de la concesión del terreno, mausoleo, capilla, sotanito o panteón ${ }^{58}$. Empero, permanece la posición pública sobre los nichos en los cementerios. Estos se constituyen intransferibles, y cuando se desocupen, haya o no terminado el periodo concedido, pasará automáticamente al poder de la municipalidad. Todo ello sin derecho a reclamo o indemnización por ningún concepto ${ }^{59}$.

El estudio de Reglamentos internos de cementerios chilenos ${ }^{60}$ demuestra la forma en que el régimen general de cementerios, repercute en la falta de concreción de un sistema definido para las sepulturas. Tal confusión parte de reconocer, por un lado, el carácter general o público del cementerio, obligándose a resguardar áreas para inhumación de indigentes ${ }^{61}$. Por otro, admite la concertación de contratos de arrendamiento (para las sepulturas temporales) y compraventas (para las perpetuas), brindándole a su vez el régimen arancelario de las concesiones municipales ${ }^{62}$. En su configuración, ratifican los plazos que brinda el Reglamento General de Cementerios, sin límites de tiempo a las consideradas perpetuas ${ }^{63}$.

Otro tanto resulta del Reglamento de Cementerios de la localidad mexicana de Fresnillo, donde las concesiones a perpetuidad se denominan "concesiones por tiempo indefinido", renovables al término de 7 años $^{64}$. Por su parte, el Reglamento de Cementerios de Güeñes, extingue las concesiones a perpetuidad en los casos que no puedan acreditarse, y se reconocen por un único término de 75 años. Además, concede el derecho funerario

56 Artículos 59 y 60 del Reglamento de Bolaños.

57 Artículos del 36 al 44 del Reglamento de El Oro de 2014.

58 Artículo 4 de la Ordenanza No 3306 de San Miguel de Tucumán de 2003.

59 Artículo 25 de la Ordenanza No 3306 de San Miguel de Tucumán de 2003.

60 Se seleccionaron entre los de más reciente promulgación: Ordenanza № 003 de Temuco de 2010; Decreto Exento No 61 de Nueva Imperial de 2012; Resolución No 6l-G.G de Valparaíso de 2017.

61 Artículo 4 de la Ordenanza No 003 de Temuco de 2010; Artículo 5 de Decreto Exento No 61 de Nueva Imperial de 2012; Artículos 3 y 4 de Resolución No 6l-G.G de Valparaíso de 2017. La doctrina reconoce además, la nulidad del acto administrativo que origina la concesión, si en su fondo o en su forma contiene una violación de los pertinentes preceptos legales, a través de la función jurisdiccional.

62 Artículos 17 y 20 de la Ordenanza No 003 de Temuco de 2010, brindan un régimen de propiedad, reconociendo la venta y arrendamiento de la sepultura; sin embargo, el artículo 34 de la propia norma, remite las formas de pago de los servicios y actuaciones administrativas del cementerio, a la OrdenAnZa Local No 002 de 1993, que en los artículos del 26 al 35, les aplica un régimen concesional; Artículo 67 de Decreto Exento No 61 de Nueva Imperial de 2012; Artículos 9 y 10 de Resolución No 6l-G.G de Valparaíso de 2017.

63 Artículo 16 de la Ordenanza No 003 de Temuco de 2010; Artículos 10 y 13 de Decreto Exento No 61 de Nueva Imperial de 2012; Artículo 27 de Resolución No 6l-G.G de Valparaíso de 2017.

${ }^{64}$ Artículos del 53 al 55 del Reglamento de Fresnillo. 
para el inmediato depósito de un cadáver por un plazo de 10 a 30 años, transmisible por donación o actos sucesorios, entre familiares y dentro del cuarto grado de consanguinidad, previo abono de la tasa correspondiente ${ }^{65}$. Por último, el Reglamento del Distrito Federal de México utiliza el término cementerios oficiales, muy abarcador en cuanto al derecho de uso, destinando su Capítulo VIII al derecho de uso sobre fosas, gavetas, criptas y nichos. Dispone para cada uno de estos bienes cementeriales el término en que se podrá ser titular del derecho de uso. Así el derecho de uso sobre las fosas se proporcionará mediante los sistemas de temporalidades mínima y máxima, entendiéndose por mínima el ejercicio de este derecho por 7 años y transcurridos estos, la fosa vuelve al dominio pleno del Departamento del Distrito Federal ${ }^{66}$.

Se suma a su vez las posturas adoptadas por la municipalidad argentina de Lomas de Zamora, para la que, paradójicamente, aunque posibilita la enajenación de sepulturas de 5 en 5 años cíclicamente, dispone la abolición de la venta a perpetuidad de dichas sepulturas. Sin embargo, reconoce el régimen de perpetuidad a los terrenos de las secciones destinadas exclusivamente para panteones o monumentos, y los nichos construidos alrededor de las paredes del Cementerio. Para ello regula que las concesiones serán renovables, caducando por el nuevo transcurso del término y volviendo a ser propiedad de la Municipalidad que no se reclamen en los 60 días siguientes a su expiración.

De acuerdo con los postulados contenidos en el Reglamento General de Cementerios chileno, mientras que los derechos sobre sepulturas perpetuas incluyen la posibilidad de inhumar a los cónyuges y parientes legítimos hasta la tercera generación ${ }^{67}$; las temporales se adquieren para el uso individual ${ }^{68}$. La transferencia del derecho de sepultura se efectúa mediante escritura pública, previa autorización del Administrador, y se inscribirá en el Registro de la Propiedad y en el de Transferencias del Cementerio ${ }^{69}$. A partir de la suscripción de los contratos domínicos, los Reglamentos internos se consideran parte integrante de ellos. Así, los contratantes se obligan a cumplir con cada una de sus disposiciones, del mismo modo que se transfieren a quienes los sucedan en sus derechos a cualquier título ${ }^{70}$.

\section{LA REGULACIÓN CEMENTERIAL CUBANA. SUS SUJETOS Y CONTENIDO}

Como se ha venido sosteniendo, los cementerios constituyen bienes públicos por naturaleza, ameritando un régimen protector por parte de la Administración, quien ejercerá

\footnotetext{
65 Artículos 22, 31 y Disposición Transitoria del Reglamento de Güeñes.

66 Artículos 59, 61 y 62 del Reglamento de Distrito Federal de 1984.

67 Artículo 11 de la Ordenanza No 003 de Temuco de 2010; Artículo 10 a) de Decreto Exento No 61 de Nueva Imperial de 2012; Artículo 10 de Resolución No 6l-G.G de Valparaíso de 2017.

68 Artículo 12 de la Ordenanza No 003 de Temuco de 2010; Artículo 13 de Decreto Exento No 61 de Nueva Imperial de 2012; Artículo 28 de Resolución No 6l-G.G de Valparaíso de 2017.

69 Artículo 38.3.4 de la Ordenanza No 003 de Temuco de 2010; Artículo 14.3.4 de Decreto Exento No 61 de Nueva Imperial de 2012; Artículo 25.3.4 de Resolución No 6l-G.G de Valparaíso de 2017.

70 Artículo 3 de la Ordenanza No 003 de Temuco de 2010; Artículo 58.7 de Decreto Exento No 61 de Nueva Imperial de 2012; Artículo 58 de Resolución No 6l-G.G de Valparaíso de 2017.
} 
su control y supervisión. De acuerdo con el Decreto-Ley 147 de 21 de abril de $1994^{71}$, con la reestructuración de los organismos de la Administración Central del Estado, transciende al sector cementerial la fusión de la Junta Central de Planificación al Ministerio de Economía y Planificación. Este a su vez, y mediante su Departamento Independiente de Servicios Comunales, asume la rectoría metodológica de las Direcciones Provinciales de Servicios Comunales, adquiriendo la actividad cementerial nivel institucional y perspectivas para su ulterior desarrollo.

En este plano, se crean las Direcciones Municipales de Servicios Comunales, que, entre sus encargos públicos, ejercen la dirección y gobierno de los cementerios, cuyas reglas de funcionamiento se implementan en las Normativas ${ }^{72}$. Poseen una doble subordinación, dependiendo de las orientaciones metodológicas que les brindan sus instancias superiores descritas, quienes emiten las normas de su funcionamiento. Asimismo, se supeditan al Órgano Municipal del Poder Popular, quien establece sus directrices administrativas y funcionales, constituyendo los cementerios, entes públicos sujetos a la municipalidad.

Aunque bien definido el sujeto actuante, su labor se enfoca mutilada al adolecer de un régimen sancionador en caso de incumplimientos. Tampoco le concede facultades decisorias ante conflictos suscitados en el marco cementerial, los que se resuelven en el ámbito judicial. Se sesga así la intervención administrativa, a pesar de reconocerse al Estado como el órgano concedente de derechos. La Administración resulta un mero ente comunicativo, sin intervención activa en las normas que enuncia, perdiendo su papel de enlace entre el sujeto pasivo y el poder que representa. La función administrativa se disuelve sin lograr la satisfacción directa de los intereses públicos, ni al indirecto ejercicio de los poderes legislativo y judicial, características inherentes a su constitución, según sus postulados teóricos.

\section{El CONTENIDO Y ALCANCE DE LA REGULACIÓN CEMENTERIAL CUBANA ACTUAL.}

Si bien el cementerio constituye un servicio público que condiciona en ese carácter a su integridad física; sobre los bienes que lo conforma se constituye un uso privado por parte de los usuarios de ese servicio, que puede resultar temporal o a perpetuidad. En el uso temporal la práctica nacional se enmarca en el permiso de uso constituido sobre bóvedas estatales, cuyo ámbito precario se reduce al exclusivo depósito de restos humanos por un término de dos años, tal como expresa el artículo 18 de las Normativas. Este postulado literalmente expone que a los familiares de los inhumados en inmuebles estatales se les comunicará que la exhumación del cadáver se realizará a los dos años y un día de inhumado ${ }^{73}$.

Respecto a su conformación, deviene en un acto administrativo bilateral, en el que la voluntad del administrado resulta esencial para su existencia. Tal condición impide que puedan otorgarse de oficio, requiriendo de una parte interesada en su otorgamiento para que se constituya. Sin embargo, ello no implica que pueda instrumentarse mediante un

\footnotetext{
71 Decreto-Ley No 147 de 1994.

72 Se exceptúan a los camposantos de Colón, Chino y Bautista en La Habana y los del municipio de Santiago de Cuba (Artículo 2 de las Indicación de 2007).

73 Si bien el término "precario" tuvo vigencia originaria en el Derecho privado, en la actualidad adquiere aplicabilidad también en el Derecho público, en el que alcanza características similares en cuanto a su conformación efectos o consecuencias, salvo norma en contrario. MARIEnHoff (1960) p. 160.
} 
contrato, al traducirse su precariedad en una mera tolerancia de la Administración. Por tanto, nada obsta que pueda extinguirlo en cualquier momento ${ }^{74}$, en contraposición con las garantías propias del contrato. En efecto, y amparados en estas ideas, autores como DuGUIT $^{75}$, sostienen que el permiso de uso no posee elemento contractual; posición que sostiene la presente obra.

En cuanto a sus efectos, el permiso de uso resulta, generalmente, un acto unilateral, pues su cumplimiento recae en el Estado concedente. Sin embargo, puede pactarse la obligación del permisionario de abonar un canon por el uso otorgado, en cuyo caso también sería bilateral, al generar en favor del Estado un derecho a su cobro. La bilateralidad se concreta entonces en la reciprocidad de obligaciones del Estado hacia el administrado, permitiéndole realizar el uso pertinente. A su vez, del permisionario hacia el Estado abonándole el respectivo canon. Este supuesto no altera la naturaleza del permiso atribuyéndole carácter contractual, pues subsisten las características del permiso ya estudiadas que impiden esta forma de constitución ${ }^{76}$.

De acuerdo a su instrumentación en las actuales Normativas, el uso de las gavetas estatales se realiza a través de un contrato escrito (artículo 6). En este aspecto, si bien se advierte la necesidad de la configuración expresa del permiso otorgado como garantía de su existencia, al tratarse de una mera autorización para el depósito de cadáveres por un tiempo determinado, la forma contractual no se adapta a sus características. En estos elementos se encuentran quizás las causas de su inutilización por un grupo importante de cementerios públicos cubanos, en los que se sigue como práctica advertir a los deudos de la exhumación, a través de la Certificación o Tarjeta de Inhumación, mientras que otros implementan una proforma de contrato.

El alcance del permiso otorgado puede vislumbrarse entre una serie de preceptos contenidos en las Normativas que requieren su sistematización. Así, durante el término de vigencia, no puede ocurrir otro enterramiento, salvo que tenga la capacidad para dos ataúdes y se trate de un familiar (artículos 127 y 140). Conlleva la abstención de realizar cualquier construcción sobre el bien (artículo 73). Impide que pueda hacerse uso del cadáver antes del tiempo estipulado para la exhumación (artículo 18). Se prohíbe la realización de actos, ya sea por parte de la Administración o un particular, que afecten el uso autorizado (artículo 140). Por último, dispone la gratuidad de la prestación estatal y el servicio público al que va dirigido.

Más controversial resultan los usos privativos que perpetuamente se han constituido sobre los bienes cementeriales cubanos, cuya indeterminación data del propio surgimiento de los primeros cementerios públicos. Precisamente durante los años 50 del pasado siglo, las titularidades de bóvedas, panteones y sepulturas se establecían como contratos de compraventa privados, mediante los que el Alcalde Municipal o el Arzobispado de La Habana,

\footnotetext{
74 A pesar de su precariedad y la discrecionalidad para su otorgamiento, la extinción del permiso de uso requiere ser motivada. De ahí que el acto que dispone su extinción debe expresar los motivos en cuyo mérito se extingue. Así se excluye lo arbitrario o lo potestativo, poniendo de manifiesto la razonabilidad o la juridicidad del acto de extinción. MarienHoff (1960) p. 169.

75 Duguit (1930) p. 376. Además, Jansse (1938) p. 295; Marienhoff (1960) p. 161.

76 Marienhoff (1960) pp. 160-163.
} 
en su caso, cedía a perpetuidad el uso de una porción del terreno cementerial por una suma de dinero. Este documento debía elevarse a escritura pública, tan pronto como el municipio lo tuviese inscripto en el Registro de la Propiedad.

Al triunfo revolucionario de 1959, en las titularidades cementeriales se continuó pactando por compraventa privada la cesión a perpetuidad de lotes de terrenos cementeriales. Igualmente se mantuvo la referencia explícita a la figura del alcalde municipal, a pesar de que este término había sido sustituido por el de Comisionados. Tales conceptos de propiedad y cesión a perpetuidad, aunque no excluyentes entre sí, pugnan en primacía al no exponerse en el documento suscrito la condición de propietario del adquirente. No obstante, estas indeterminaciones no resultaron óbice para impedir el tráfico jurídico de sus bienes, ya sea en la vía administrativa, como en la vía civil y notarial.

En el ámbito cementerial cubano, el uso privativo sobre bóvedas, panteones y mausoleos, se reconoce como propiedades particulares. En razón de la titularidad, la Administración garantiza una serie de prerrogativas en el uso y disfrute del bien. En su configuración se intenta evitar la contradicción que genera el reconocimiento de una propiedad personal bajo las reglas y condiciones del Derecho Civil al prohibir su venta (artículo 147 Normativas). De ello se entiende que el terreno sobre el que se asienta un cementerio público, adopta la misma condición jurídica de aquél, e impide que puedan fragmentarse sus áreas para entrar a un régimen privado. Por lo que al devenir en cosa fuera del comercio, los actos jurídicos efectuados deben atenerse a su naturaleza ${ }^{77}$.

Otro análisis amerita la construcción de bienes cementeriales, tales como bóvedas, panteones, y las instalaciones de estatuas, jardineras y otros elementos. Ello resulta la materialización del derecho de uso nacido de la concesión. Estas construcciones e instalaciones, aunque pertenecen al concesionario, no son bienes de naturaleza civil; sino que, en virtud de generarse a partir de un acto concesional, se manifiestan como derechos subjetivos públicos, cuyas características y consecuencias se derivan de la concesión. Entonces, su edificación constituye el medio por el que el concesionario ejercita el derecho de sepultura concedido ${ }^{78}$.

Todo lo anterior patentiza el criterio de que los bienes cementeriales edificados, si bien resultan propiedad del concesionario, se rigen por el Derecho público. Su contenido se configura bajo las normas y principios del Derecho administrativo, y especialmente, por las que sustentan a la concesión. Es por ello que la solución de los conflictos generados, deberá encausarse en esta rama jurídica. La extensión de los derechos y facultades de enajenación, también son materia administrativa. Aún más, las relaciones de derecho privado constituidas entre el concesionario y terceros, han de seguir igual suerte ${ }^{79}$.

\footnotetext{
77 En este sentido, los importes abonados no deben considerarse en calidad de precio, sino de canon. En todo caso, a esos importes corresponde el carácter de canon por el uso de un bien público, amortizado en un solo acto. Marienhoff (1960) pp. 259-263; Fernández de Velasco (1935) p. 205; Sarría (1957) pp. 287-288; Caetano (1970) p. 587; Villegas (1952) pp. 423, 426 y 427; Le Balle (1924) p. 108.

$78 \mathrm{Al}$ decir de Zanobini, en materia de uso del dominio público, el sepulcro posee la misma naturaleza legal que las obras que cualquier otro concesionario de uso realiza para ejercitar el derecho concedido. Su naturaleza no difiere de la de los otros derechos reales administrativos que, basados en una concesión de uso, pueden constituirse sobre bienes demaniales. ZANOBInI (1954) p. 99.

79 Marienhoff (1960) pp. 261.
} 
En cuanto al otorgamiento de la concesión de uso, se sostiene por un grupo de autores que constituye un deber de la Administración Pública ${ }^{80}$. Para otros, se trata de una facultad discrecional y por ende, la autorización de la concesión no es obligatoria ${ }^{81}$. De estas ideas, se acoge el criterio seguido por MAYER, y que expresa que tal potestad se enmarca en la discrecionalidad de la Administración Pública para decidir si conferirla o no. Para que exista obligación de otorgarla, se requiere que esté reglada, y se cumplan las condiciones requeridas por la ley. En el ámbito cementerial, la concesión debe establecerse en norma, siendo un acto obligatorio de la Administración, en razón del servicio público al que responde ${ }^{82}$.

Respecto a su conformación, se le reconoce en la doctrina la bilateralidad existente entre ambos sujetos desde el punto de vista sustancial y formal. Así, requiere la concurrencia de la voluntad del Estado y la del administrado, creando recíprocos derechos y obligaciones entre ellos, lo que fija el status de las partes ${ }^{83}$. En tal situación, si bien el Estado no puede alterar los términos de la concesión, imponiéndole otras cargas distintas a las asumidas ab-initio, le permite declarar caduca la concesión, si el concesionario no cumple las obligaciones pactadas. Ello implica que pueda formalizarse por la vía de un acto o contrato administrativo ${ }^{84}$.

Las obligaciones recíprocas generadas conminan al Estado a permitir que el concesionario utilice la respectiva porción del bien demanial. A su vez, comprometen al concesionario a contribuir al aumento del bienestar públicos, mediante la adecuada utilización del bien cuyo buen uso es de interés público. Además, pueden establecerse otras obligaciones accesorias, como el pago de un canon. Al decir del profesor Matilla Correa, más que contrato o acto administrativo, la concesión se enfoca como derecho, procedimiento y título jurídico-administrativo. De esta forma, se puede considerar como documento formal que contiene el acto en cuestión; y como forma de gestionar un servicio público ${ }^{85}$.

De otra parte, cabe valorar que, en el caso específico de las concesiones de uso cementeriales, la mayor o menor duración no afecta su naturaleza. Del mismo modo, tampoco influye en dicha naturaleza la gratuidad u onerosidad de la concesión. Esto significa que la relación jurídica administrativa constituida entre los particulares y el Estado, cuyo objeto se encamina al uso de los osarios estatales, una vez efectuada la exhumación y reducción de cadáveres, también se enmarcan en el régimen concesional. Tal uso, perpetuo por su trascendencia social, requiere asentarse sobre una sólida base legal, que genere un derecho

${ }^{80}$ Holtz et al. (1929) p. 48; CASTello (1921) pp. 249-250.

81 Gay de Montella (1927) pp. 247 y 252; Sarría (1943) pp. 74-79.

${ }^{82}$ MAYer (1950) pp. 252-253.

${ }^{83}$ En este sector destacan: Pacelli (1918) p. 240; Duguit (1930) p. 376; Lafaille (1944) p. 101; Waline (1936) p. 453; Trotabas et Isoart (1978) p. 142; Villegas (1952) pp. 225 y 237-246; De Laubadère (1956) pp. 46-50; BerÇattz (1952) pp. 5-7; Argañarás (1955) p. 114.

${ }^{84}$ Sobre la concesión administrativa como acto o contrato administrativo y su relevancia para la normativa cubana vigente en la materia, ver MATILLA (2009) pp. 126-140.

${ }^{85}$ El acto administrativo y el contrato administrativo son las formas básicas de instrumentación de las relaciones jurídicas concretas de carácter bilateral que se establecen al amparo del Derecho Administrativo. Matilla (2005) pp. 44-45. 
público subjetivo, y ofrezca garantía y seguridad; lo que se logra mediante la figura iuris de la concesión.

En otro orden, las Normativas en estudio instrumentan en su artículo 96, la figura del usufructo de una instalación o parcela. Evidentemente, su clara referencia ampara los derechos que en este concepto pudieron haberse constituido en cementerios públicos cubanos. No obstante, no ha podido constatarse su otorgamiento, por lo que se desconoce el modo en que se ha constituido. Al respecto, existe consenso en la doctrina, al afirmar la incompatibilidad de esta institución con los principios que regulan el uso de los bienes demaniales. En todo caso, la posibilidad que reconoce los artículos del 211 al 213 del Código $\mathrm{Civi}^{86}$, de que se otorguen en este concepto bienes estatales, se refiere a los bienes patrimoniales del Estado ${ }^{87}$.

Precisamente, tal concepto resulta inaplicable a los bienes integrantes del dominio público, pues mientras que el usufructo se otorga siempre intuitu personae, en el uso privativo de bien demanial puede ser otorgado intuitu rei, al considerarse la cosa antes que a la persona. Posee siempre un carácter temporario, teniendo como duración máxima la vida del usufructuario; en cambio el uso privativo puede ser perpetuo. Los derechos del usufructuario no se trasmiten a sus herederos, en tanto que en los segundos generalmente pueden trasmitirse ${ }^{88}$.

De manera general, las Normativas instrumentan derechos y responsabilidades de los titulares de bienes cementeriales. Entre ellos destaca la autorización de los representantes, para las inhumaciones en panteones de veteranos, combatientes, logias, etcétera (artículo12 y 31). De igual forma, se requiere presentar el documento de propiedad del bien cementerial y la autorización del propietario para realizar inhumaciones en él (artículo 15 y 36). Se prohíbe al propietario efectuar la exhumación de cadáver en su propiedad sin la presencia de familiar o allegado (artículo 47). Se reconoce la posibilidad de conservar en el bien cementerial particular los restos humanos, mientras tenga capacidad (artículo 49).

Se establece a su vez en su Capítulo IV, un procedimiento para la construcción de bienes cementeriales en el que se significan las condiciones a cumplir, por razones de salubridad, arquitectónicas o distributivas (artículos del 57 al 75). Impone la obligación de respetar los restos óseos existentes, tanto en bienes particulares que pasan al régimen estatal, como a los adquirentes por herencia (artículos 76 y 77). Reconoce la posibilidad de efectuar permutas entre particulares (artículo 95). Por último, dispone la obligación del titular de mantener el bien cementerial en óptimas condiciones (artículos 96 y 113).

\section{CONCLUSIONES}

Como ya se ha abordado, los sujetos y contenido de la relación jurídica cementerial han sido ampliamente debatidos en la doctrina. Sin embargo, aunque se evidencian nota-

\footnotetext{
86 LEY No 59 de 1987.

87 Ducroce (1900) p. 356; Lazo (1930) pp. 162-163; Villegas (1952) p. 140; De Laubadère (1956) p. 766.

88 Para constituir un derecho de usufructo sobre bienes del dominio público, deben desafectarse; de lo contrario el acto carecería de valor por la inidoneidad de su objeto. Marienhoff (1960) p. 113.
} 
bles pasos de avances entre una regulación y otra, no ha alcanzado un desarrollo sostenido y general en los ordenamientos estudiados. En ellos logra identificarse al Estado como sujeto activo de la relación jurídica cementerial, y como pasivo a los administrados que resulten usuarios del servicio de cementerio. Entre ambos sujetos se genera una relación desigual, con fuerte predominio de la Administración, cuya función coadyuva a la defensa del patrimonio demanial. Esta supremacía del ente administrativo se encuentra entonces supeditada a las potestades que al efecto se le reconoce en el ámbito municipal. Como órgano ejecutor, cada municipalidad tiene a su cargo los cometidos del servicio público, que incluye a cementerios y panteones, en razón de sus condiciones territoriales y socioeconómicas y de su capacidad administrativa y financiera.

Evidentemente, la esencia demanial de los cementerios públicos, atribuye igual naturaleza jurídica a las sepulturas incorporadas a ellos. En este aspecto, es importante poner atención a la naturaleza jurídica del bien: cementerio, para determinar que en el caso de los derechos constituidos sobre sepulturas y panteones se trata de un permiso de uso privativo de bien público, y no de una venta o compra de bienes ni de un contrato traslativo de dominio, mucho menos de arrendamientos. Son bienes de dominio público. Tal situación pondera un servicio público, en virtud de lo cual se encuentran sujetos al poder de policía mortuoria ${ }^{89}$ destinado a su uso privativo, que deviene en el acto jurídico en cuyo mérito los particulares pueden adquirir derechos. Así, se garantiza que la sepultura sea únicamente utilizada de acuerdo con su fin, por personas que hayan adquirido facultad para ello. Su materialización se lleva a cabo a través de los medios que al efecto establezca o reconozca la normativa vigente en el lugar ${ }^{90}$. En tal sentido pueden ser, el permiso de uso ${ }^{91}$ aplicado por la Administración para que los usuarios aprovechen y usen los cementerios; y la concesión de uso ${ }^{92}$ para actividades de importancia jurídica-económica-social ${ }^{93}$.

Como rasgo esencial, en las normativas cementeriales sobresale la ausencia de una cohesión en los entes administrativos nacionales que sistematicen un tratamiento homogéneo para todos los municipios. De esta forma, no queda claro el acto administrativo por el cual se genera la relación Administración-usuario, pues subyace una fuerte sujeción al tratamiento civil de panteones y sepulturas sustraídos de su esencia demanial. Además, y ante los procesos de liberalización de servicios públicos experimentado en el contexto lati-

\footnotetext{
89 Fernández de Velasco (1935) p. 162.

90 Marienhoff (1960) pp. 259-260.

91 El permiso, como indica Garrido Falla, está sometido expresa o tácitamente a la posibilidad de que la Administración en cualquier momento pueda revocarlo por razones de interés público, sin derecho alguno del particular a indemnización, es decir, se otorgan expresa o tácitamente a título de precario. GARRIDO FaLLA (1986) p. 471.

92 Desde una perspectiva amplia, puede decirse que la concesión genera el nacimiento de un derecho para determinada persona, ya porque se lo otorga la Administración Pública, ya porque estaba establecido en las normas positivas, pero requiere de un acto administrativo para hacerse efectivo. Matilla (2009) p. 36.

$93 \mathrm{Al}$ respecto, Fernández de Velasco afirma que a partir de la apertura de un cementerio público y hasta su clausura, todas las actividades que componen el servicio público, las clases y distribución de sepulturas, los servicios fúnebres, el orden y régimen interior del cementerio, la conducción de cadáveres, forman parte de la función de policía que corresponde al Ayuntamiento, entendido como la Administración. FERnÁndEZ DE Velasco (1935) p. 162.
} 
noamericano, la gestión privada de cementerios permite a los Ayuntamientos concesionar los servicios funerarios que comprenden desde el fallecimiento, hasta el acto del sepelio, incluyendo los rituales funerarios y velatorios. En todo caso, la incidencia del interés público sobre las situaciones jurídicas privadas, debe ceñirse a una coexistencia pacífica y a una delimitación del contenido esencial del dominio derivada de la subordinación al bien común. Situación que no puede conducir a una negación de los derechos subjetivos. La imposición de situaciones de sacrificio del interés particular exige que de ello se derive una auténtica y proporcionada ventaja para la colectividad y para el interés general ${ }^{94}$.

El reconocimiento de titularidades privadas insertadas en bienes de dominio público, como resulta el caso de los cementerios, entraña la imposibilidad del particular de ejercitar el señorío pleno sobre el bien. Ello se debe a que la vinculación del bien al fin o destino público, como elemento condicionante de su demanialidad, se materializa en un ius in re aliena en poder de la Administración. Posibilita a su vez la potestad administrativa de la transmisión de la propiedad a través de las vías oportunas negociadas o coactivas, si ello se requiere para la plena efectividad de los fines públicos inmanentes al demanio. Esta concepción, de acuerdo con el criterio de PAREjo Alfonso ${ }^{95}$, ofrece respuesta idónea a los fenómenos de disociación entre titularidad y afectación, así como a la incidencia del interés público sobre bienes de propiedad privada.

Resulta así evidenciado que el régimen de los cementerios públicos requiere una regulación administrativa que organice su funcionamiento, y vele por el cumplimiento de los requerimientos administrativos en el uso de los bienes cementeriales. En los sistemas jurídicos latinoamericanos estudiados, sucede que, al resultar tan intensa la incidencia del interés público en los cementerios sobre los derechos privados constituidos en los sepulcros, se yuxtapone al régimen ordinario de propiedad privada, un régimen público. Régimen este que afecta el normal desenvolvimiento y ejercicio de las facultades demaniales integrantes de la propiedad. Actúan sobre ellas limitaciones administrativas, en el orden de su transmisibilidad, y en cuanto a poderes de suspensión, vigilancia o limitaciones de su aprovechamiento o disponibilidad. En este sentido, ha sido en la regulación chilena donde se implementa una ordenación coherente para todas sus municipalidades.En contraste con las regulaciones estudiadas, el ordenamiento cementerial cubano a penas sistematiza las cuestiones más elementales del régimen jurídico de los cementerios públicos. De acuerdo con los postulados de las Normativas Técnicas para el Trabajo en los Cementerios, emitidas en diciembre de 2007 por el Ministerio de Economía y Planificación, resultan las Direcciones Municipales de Servicios Comunales, quienes ejercen la dirección y gobierno de los cementerios municipales. El órgano administrativo se aprecia mutilado en su actuación, sin intervención activa y directa sobre la aplicabilidad de las normas que enuncia.

A su vez, exponen un régimen sobre bóvedas estatales, encaminado al exclusivo uso para el depósito de cadáveres por un término de dos años. Además, reconoce propiedades particulares sobre bóvedas, panteones y mausoleos, garantizados por una serie de prerro-

\footnotetext{
4 Pérez Gálvez (1999) pp. 247-260.

95 Parejo Alfonso (1983) pp. 2379-2422.
} 
gativas en el uso y disfrute del bien cementerial. En tales casos se trata de usos privativos constituidos sobre el demanio cementerial otorgados en razón del permiso de uso o de la concesión de uso. Ello implica que el cementerio como unidad física estatal se encuentre sujeto a la inscripción registral. También permite que la concesión constituida como derecho real alcance su protección registral, de conjunto al derecho de propiedad constituido sobre el bien cementerial edificado.

La demanialidad de los cementerios públicos es un hecho indubitado, a la luz de su surgimiento y evolución. No obstante esa demanialidad, que provoca un régimen jurídico exorbitante al Derecho privado, en modo alguno obsta el reconocimiento de derechos privados. Es por ello por lo que, aunque el reconocimiento de situaciones jurídicas privadas en el seno del demanio pueda resultar generalmente un fenómeno excepcional, resulta jurídicamente admisible en el marco del Derecho público. La armónica coexistencia entre derechos públicos de la Administración y privados de los particulares, es muy frecuente en algunos sectores del demanio como el marítimo-terrestre, el hidráulico, el viario y el excepcional régimen de los cementerios públicos.

\section{BIBLIOGRAFÍA CITADA.}

Argañarás, Manuel. J. (1955): Tratado de lo contencioso administrativo (Buenos Aires, Editorial Tipográfica Editora Argentina).

Ballbé Mallol, Manuel (1948): Concepto del Dominio Público (Barcelona, Editorial Bosch).

Ballesteros Moffa, Luis Ángel (1990): Manual de Bienes de las Entidades Locales (Madrid, Editorial del Ministerio para las Administraciones Públicas).

Beladiez Rojo, Margarita (1997): Responsabilidad e imputación de daños por el funcionamiento de los servicios públicos (Madrid, Editorial Centro de Estudios Ramón Areces).

BerçAitz, Miguel Ángel (1952): Teoría General de los Contratos Administrativos (Buenos Aires, Editorial Depalma).

BIELSA, Rafael (1956) : Derecho administrativo, Tomo III (Buenos Aires, Editorial Depalma, quinta edición).

Caetano, Marcello (1970): Manual de Direito Administrativo, Tomo I (Rio de Janeiro, Companhia Editora Forense, primeira edição brasileira).

Cammeo, Federico (1926): "Demanio", en Cammeo et al., Il Digesto Italiano, Volume IX (Torino, Unione Tipografico-Editrice Torinese) pp. 896-925.

Cassagne, Juan Carlos (2001): "Evolución de los principios aplicables a los servicios públicos y problemas actuales tras los procesos de privatización en Argentina", Revista de Administración Pública, No 154: pp. 441-461.

Castello, Manuel F. (1921): Legislación de aguas: tesis presentada para optar al título de doctor en jurisprudencia y recomendada al premio Facultad (Buenos Aires, Editorial Tixi y Schaffner).

Convenios de Ginebra y sus Protocolos Adicionales, Ginebra (12 de agosto de 1949).

Cornejo, Américo Atilio (1994) : Derecho Registral (Buenos Aires, Editorial Astrea). 
De Laubadère, André (1956) : Traité théorique et pratique des contrats administratif, Tome I (Paris, Librairie Générale de Droit et de Jurisprudence).

De Laubadère, André (1958) : Droit Administratif Spécial (Paris, Presses Universitaires de France).

Ducroce, Theodore (1900) : Cours de Droit Administratif, Tome VI (Paris, Ancienne Librairie Thorin et Fils. A. Fontemoings Éditeurs).

Duguit, León (1930) : Traité de Droit Constitutionnel, Tome III (Paris, Ancienne Librairie Fontemoing \& $\mathrm{C}^{\mathrm{ie}}$, Éditeurs).

Fernández de Velasco, Recaredo (1935): Naturaleza jurídica de cementerios y sepulturas: historia y problemas jurídicos (Madrid, Editorial Revista de derecho privado).

Fernández, María Lucía et al. (2016): "Los cementerios territorios de memoria urbana e identidad". Disponible en: https://rdu.unc.edu.ar/bitstream/handle/11086/5753/3.1.\%20 Los\%20cementerios\%20territorios\%20de\%20memoria. pdf? sequence $=32 \&$ isAllowed $=y$. Fecha de consulta: 22 de enero de 2018 .

García de Enterría Eduardo y Fernández, T. R. (1997): Curso de Derecho Administrativo, Tomo I (Madrid, Editorial Civitas, octava edición).

GaRCía Rondón, Caridad (2006): Las normas de protección jurídico-penal a los cementerios y otros importantes sitios de enterramiento en Cuba, Tesis en opción al grado académico de Máster en Derecho Penal en la Facultad de Derecho de la Universidad de Oriente.

Garrido Falla, Fernando (1986): Tratado de Derecho Administrativo, Volumen II. Parte General: Conclusión (Madrid, Centro de Estudios Constitucionales, séptima edición).

Gay de Montellá, R. (1927): Teoría y práctica de la legislación de aguas (Barcelona, Editorial Bosch).

GuicCiardi, Enrico (1934): Il Demanio (Milano, Editorial CEDAM).

Hauriou, Maurice (1929): La Jurisprudence Administrative de 1892 à 1929, Tome I (Paris, Librairie du Recueil Sirey).

Hernández, Ronaldo (2008): “Situación Jurídica de los Cementerios Públicos”. Disponible en: http://sitios.poderjudicial.go.cr. Fecha de consulta: 29 de enero de 2018.

Holtz, Kreutz y Schlegelberger (1929) Das Preussische Wassergesetz (Berlin, Heymann).

Irarrázaval Gomien, Andrés (2018): "Hacia un nuevo consenso en la regulación de los cementerios: la evolución de las normas civiles y canónicas a lo largo del S. XX”, Revista Chilena de Derecho, vol. 45, No 1: pp. 33-56.

JansSe, Lucien (1938): Les traits principaux du régime des biens du domaine public (Paris, Editorial Dalloz).

Lafaille (1944): Tratado de los Derechos Reales, Tomo II (Buenos Aires, Editorial Tipográfica Editora Argentina).

Lazo Preuss, Santiago (1930): Régimen legal de las aguas corrientes (Santiago, Editorial La Ilustración).

LE BALLE, Robert (1924): De la nature du droit du concessionnaire de sépulture (Paris, Librairie Dalloz).

López Pellicer José A., y Sánchez Díaz, José L. (1976): La concesión administrativa en la esfera local. Servicios, obras y dominio público (Madrid, Editorial del Instituto de Estudios de Administración Local). 
Marienhoff, Miguel S. (1960): Tratado de Derecho Administrativo, Tomo V (Buenos Aires, Editorial Depalma).

Martín-Retortillo, Sebastián (1963): "Responsabilidad de la Administración pública por lesión de intereses legítimos”, Revista de Administración Pública, No 42: pp. 453-489.

Matilla Correa, Andry (2005): Fundamentos del régimen jurídico de las concesiones administrativas. Una visión cubana, Tesis en opción al grado científico de Doctor en Ciencias Jurídicas en la Facultad de Derecho de la Universidad de La Habana.

Matilla Correa, Andry (2009): Introducción al régimen jurídico de las concesiones administrativas en Cuba (La Habana, Editorial Universitaria).

MAYER, Otto (1950): El derecho administrativo alemán, Tomo III (Buenos Aires, Editorial Depalma).

Navarro, A. (1988): "La ampliación de la responsabilidad patrimonial de la Administración a los daños ocasionados por sus funcionarios o agentes actuando al margen del servicio público", Revista REDA, No 60: pp. 603-678.

Pacelli, Francesco (1918): Le acque pubbliche (Torino, Editorial Giappichelli).

Parada VázQuez, José Ramón (1988): Derecho Administrativo (Bienes públicos y urbanismo) (Madrid, Editorial Marcial Pons).

Parejo Alfonso, Luciano (1983): "Dominio público: un ensayo de reconstrucción de su teoría general”, Revista de Administración Pública, Núm. 100-102: pp. 2379-2422.

Parejo Alfonso, Luciano (2009): "El régimen jurídico legal general de los bienes públicos", en Parejo Alfonso, Luciano y Palomar Olmeda, A. (Dir.), Derecho de los bienes públicos, Tomo I (Cizur Menor, Editorial Aranzadi).

Pérez GÁlvez, Juan Francisco (1999): "Responsabilidad patrimonial de la Administración municipal por traslado de restos de un nicho a otro. (Sentencia del Tribunal Supremo de 19 de enero de 1999. Ponente: Exmo. Sr. D. Pedro Antonio Mateos García)", Revista Jurídica de Navarra, Núm. 27: pp. 247-260.

Ranelletti, Oreste (1897): Concetto, natura e limiti del demanio pubblico (Torino, Rivista Giurisprudenza Italiana, Unione Tipografico-Editrice Torinese).

Ranelletti, Oreste (1945): Teoria degli atti amministrativi speciali (Milano, Dott. A. Giuffrè - Editore, settima edizione riveduta e integrata).

Rodríguez Blanco, Miguel (2015): Régimen Jurídico de cementerios y sepulturas (Granada, Editorial Comares S. L.).

Sánchez Morón, Miguel (1997): Los Bienes Públicos (Madrid: Editorial Tecnos S.A.).

SARría, E. (1957) Derecho Administrativo (Bogotá, Editorial Temis).

SARría, Félix (1943) Teoría del Recurso Contencioso-Administrativo (Córdoba, Editorial Assandri).

Serrano, S. (2009): ¿Qué hacer con Dios en la República? Politica y secularización en Chile (1845-1885) (Santiago, Editorial Fondo de Cultura Económica).

Terradillos, Juan Manuel (2010): "Ideología y valores religiosos en el Código Penal. La reforma (siempre) pendiente", en Revista Laicidad y Libertades. Escritos Jurídicos, No 10: pp. 424-461.

Trotabas, Louis et Isoart, Paul (1978) Manuel de Droit Public et Administratif (Paris, Librairie Générale de Droit et de Jurisprudence, dix-neuvième éditions). 
Villegas Basavilbaso, Benjamín (1952): Derecho Administrativo, Tomo IV (Buenos Aires, Editorial Tipográfica Editora Argentina).

Waline, Marcel (1936) : Manuel Élémentaire de Droit Administratif (Paris : Librairie du Recueil Sirey).

Zanobini, Guido (1954): Curso de Derecho Administrativo, Volumen I Parte General (Buenos Aires, Editorial Ayadú).

\section{NORMAS CITADAS}

\section{Argentina}

Constitución Nacional de la República Argentina (22/8/1994).

Ordenanza No 838 (23/6/1983) Municipalidad de la ciudad de Santiago del Estero, Código de Cementerios.

Ordenanza No 3306/03 (12/3/2003) Municipalidad de la ciudad de San Miguel de Tucumán.

Ordenanza No 545 (27/6/1915) Municipalidad de la ciudad Lomas de Zamora, modificada por las Ordenanzas No 1419 (7/1/1949), No 1546 (19/9/1952), No 4200 (14/9/1984), No 7045 (14/12/1993), No 9896 (28/6/2001) y No $11.380(6 / 6 / 2006)$.

\section{CHILE}

Código Civil de Chile (1/1/1857) actualizado al año 2000.

DeCreto con Fuerza de Ley No 725 (11/9/1967), modificado mediante LeY No 20.533 (13/9/2011), Código Sanitario.

DeCreto No 357 (15/5/1970), modificado Decreto No 4 (8/2/2006), Reglamento General de Cementerios.

Decreto Exento No 61 (18/12/2012), Reglamento No 12 de Cementerio de la I. Municipalidad de Nueva Imperial.

Resolución No 61-G.G./2017 (25/4/2017) Reglamento de los Cementerios Nos 1,2 y 3 de Valparaíso administrados por la Corporación Municipal de Valparaíso para el Desarrollo Social.

Ordenanza Local No 002 (24/12/1993) sobre Derechos Municipales por Concesiones, Permisos, Ocupación de Bienes Nacionales de Uso Público, Propaganda y otros Servicios.

Ordenanza No 003 (28/7/2010) Funcionamiento del Parque Cementerio General de Temuco.

CUBA

Ley No 59 (16/7/1987), Código Civil de la República de Cuba.

Decreto-Ley No 147 (21/4/1994) De la restructuración de los órganos de la Administración Central del Estado.

IndiCACión del Ministerio de Economía y Planificación (diciembre/2007), Normativas técnicas para el trabajo de los cementerios.

\section{MÉXICO}


Constitución Política de los Estados Unidos Mexicanos (26/2/2013).

LeY No 7 (2/4/1985), Bases del Régimen Local.

Real Decreto Ley No 7 (7/7/1996), Norma que liberaliza los servicios funerarios.

Ordenanza (17/1/1998) Reguladora de los Requisitos para la Prestación de Servicios Públicos Funerarios en el municipio de Guadalajara.

Reglamento (28/12/1984) de los Cementerios del Distrito Federal.

Reglamento de Cementerios Municipales para el Municipio de Bolaños, Jalisco.

Reglamento (22/5/2014) de los Cementerios del Ayuntamiento Constitucional de El Oro.

Reglamento Municipal de Panteones de Fresnillo.

Reglamento de régimen interior de los Cementerios Municipales de Güeñes. 
